Article

\title{
Linking Corporate Social Responsibility to Customer Loyalty through Co-Creation and Customer Company Identification: Exploring Sequential Mediation Mechanism
}

\author{
Ali Raza ${ }^{1, *(\mathbb{D}}$, Amer Saeed ${ }^{2, *(\mathbb{D}}$, Muhammad Khalid Iqbal ${ }^{1}$, Umair Saeed ${ }^{3}$, Imran Sadiq ${ }^{2}$ and \\ Naveed Ahmad Faraz 4 (D) \\ 1 Knowledge Unit of Business, Economics, Accountancy, and Commerce, University of Management and \\ Technology, Sialkot 51310, Pakistan; khalid.iqbal@skt.umt.edu.pk \\ 2 School of Business and Economics, University of Management and Technology, Lahore 54770, Pakistan; \\ imran.sadiq@umt.edu.pk \\ 3 Business Administration Department, College of Sciences, Ministry of Higher Education, Ibri 511, Oman; \\ umairsaeed.ibr@cas.edu.om \\ 4 School of Management, Wuhan University of Technology, Wuhan 430070, China; \\ naveedahmad@whut.edu.cn \\ * Correspondence: aliraza@skt.umt.edu.pk (A.R.); amer.saeed@umt.edu.pk (A.S.)
}

Received: 14 February 2020; Accepted: 20 March 2020; Published: 23 March 2020

\begin{abstract}
Promoting corporate social responsibility (CSR) and co-creation has become a crucial relationship marketing strategy for the banks. This research empirically investigates how banks' CSR activities generate positive customer responses in the form of co-creation, customer-company identification (CCI), and loyalty. This research sheds light on the influence of CSR on customer behavior by analyzing the underlying psychological processes through the sequential mediation of co-creation and CCI. Working with a sample of 280 banking customers in Pakistan, partial least square based structural equation modeling (PLS-SEM) is employed to test the conceptual model. CSR is a multidimensional formative construct that affects customer loyalty both directly and indirectly. Sequential partial mediations of co-creation and CCI are found between CSR activities and customer loyalty. Lastly, CCI has a direct and significant impact on co-creation and customer loyalty. Banks must include CSR in their long-term marketing plans to improve overall customer behavior because banks' CSR activities result in customer identification and co-creation. Similarly, banks should welcome the customers' participation in service design and use their knowledge and skills to improve overall service culture.
\end{abstract}

Keywords: corporate social responsibility; co-creation; customer-company identification; customer loyalty; customer behavior; developing country; sustainability

\section{Introduction}

The banking crises and financial scandals in 2008 hurled many retail banks into mayhem, resulting in their closures, mergers, and acquisitions. Customer confidence was gravely corroded and needed to be fully restored. This falling customer confidence in banking institutions resulted in lower satisfaction and trust, thus leading to an adverse impact on their loyalty intention, and customer turnover has become a constant scourge of businesses [1]. Nevertheless, customer loyalty has a powerful influence on business performance as it is directly associated with lower marketing costs and higher profitability [2]. Similarly, in this era of fierce competition, organizations are trying to cope 
with their rivals through different marketing strategies [3], accentuating the fact that incorporating Corporate Social Responsibility (CSR) is an efficient way to sustain the business. Homogenization and standardization in the banking sector have also made it more troublesome for the banks to use service quality, branch environment, and location to retain customers. Therefore, nowadays, finding ways to restore confidence and to regain customer loyalty has become imperative for banking institutions across the world. Studies have confirmed that CSR is an effective marketing strategy to gain customer loyalty [4]. CSR compels customers to stick to the company's core mission and add value through positive, participatory behavior [5]. It is also observed that customers may reciprocate CSR in terms of their trust, brand identification, brand image, and loyalty [6]. Therefore, companies engaged in CSR activities result in better corporate performance thanks to the improvement of customer loyalty $[7,8]$. Consequently, it becomes a competitive advantage for most of the companies in any business industry [9].

Marketing scholars also contended on the fact that companies sometimes engage in socially responsible behavior just to gain social legitimacy. A common term "CSR washing" is all about using false CSR claims to improve the organizational standing in terms of its reputation, competitive advantage, and to gain trust from the stakeholders. Customers are becoming more skeptical about the intentions of the companies to engage in CSR activities [10]. Customers fear that companies use CSR to manipulate them, and it is not more than a gimmick. Likewise, customer skepticism about those firms is increasing, which takes the opportunistic advantage of sustainable development [11].

Moreover, customers attribute negativity towards CSR motives when they think companies' promotional efforts overstate the actual outcomes [12]. Customer responses to CSR are complex, and customers may negatively react to CSR activities when motives of the firms are in question, i.e., profit serving purpose. Foreh and Grier [13] believed that the firm's profit-driven CSR practices might harm the firm reputation. Hence, there is still debate on the CSR implications for the organizations, whether CSR doctrine is gravely flawed, or it can develop mechanisms to promote and flourish the sincere CSR programs [14].

Recently, a paper by Osakwe and Yusuf [15] contended that customers are likely to support the companies through their positive behavior, regardless of their motives behind CSR commitments. Research on electronic word of mouth claims that CSR does have a positive effect on company reputation, financial, and social performance [16]. Another stream of researchers has made less sweeping claims that the perception of CSR-washing is a way to dissuade customers from purchasing CSR products and to discourage firms from participating in CSR programs [11,14]. From an extensive review of popular media, practitioners' record, and academician's point of view through published journal articles, Pope and Wæraas [14] argued that there is five sine qua non to be fulfilled for a successful CSR-washing. Furthermore, opposite to a famous general belief, they proved that a successful CSR-washing is quite uncommon. It is argued that there are several avenues through which stakeholders and particularly consumers can measure the CSR performance. For instance, CSR indices, different watch groups, CSR rating agencies, law suits from the competitors of alleged CSR washers, and customer education schemes in the form of blogs, magazines, and news from different sources. These avenues for the measurement of CSR performance have deepened in recent years and work to expose CSR washers for higher publicity criticism.

Customers in this digitized and transparent environment are pushing companies to adopt certain CSR practices and co-creation activities [7]. A firm must interact with its customers to gain comprehension of their needs and wants as customers represent one of the most critical opportunities for innovation and value co-creation [17]. Co-creation is "an active, creative and dynamic process aimed at developing service innovations through collaborative customer interactions and relationships" [18]. According to service-dominant logic (SDL), the customer is a potential source of co-creation, and they should not be considered passive receivers of value; instead, they should act as partners and co-creators. When organizations embrace co-creation, it results in several advantages in the form of cost efficiencies, risk reduction, competitive advantage, and better insights [7]. Both co-creation and CSR come under 
the umbrella of social and collaborative processes. Customers perceive corporate values through CSR, and once customers understand fundamental corporate principles, they exhibit company favoring responses through co-creation [5,8]. Companies can co-create with customers through product development, changes in the firm structure, or even creating an influence on customer preferences [19]. Different scholars such as Prahalad and Ramaswamy [20] established four variables in banking that linked to co-creation, i.e., dialogue, access, risk assessment, and transparency. These four factors, which are also called the DART model used for co-creation, enable companies to engage customers better. Likewise, in retail shops of Italy, transparent sharing of information results in co-creation [19]. But, little literature is available on how and why CSR influences co-creation in the retail banking sector. Although some research has been conducted in Western countries [1,7] as per the author's knowledge, no study has investigated this relationship in an Asian context.

Furthermore, past studies have linked co-creation to emotional aspects such as affectivecommitment, and limited empirical research has related to customer behavioral aspects and particularly customer loyalty [7]. In addition to this, no empirical evidence has been found linking co-creation to customer-company identification (CCI). To the best of the author's knowledge, no study simultaneously examines CSR, co-creation, CCI, and customer loyalty.

To address these shortcomings in the literature as mentioned above, this paper examines the impact of banks' CSR activities on customer loyalty. Similarly, this study also adds to the literature by investigating the effect of customer-company identification (CCI) on co-creation through social identity theory. Another objective of this research is to examine the mediating effect of co-creation and CCI between CSR and customer loyalty and to unearth the underlying multiple and sequential mediation mechanisms.

Lastly, most of the research linking CSR to consumer behavior has been conducted in developed countries [21], and findings of these studies show that more research is required in the context of developing countries [22]. Developing countries constitute expanding economies and probably have more social and environmental impact compared to developed economies. Moreover, the banking sector of Pakistan is the backbone of the economy. It facilitates the growth and development of industries through money supply in the form of credit access to poor and business enterprises [23]. The banking sector in Pakistan is heavily engaged in CSR activities in the form of philanthropic work, cause-related marketing, and environmental protection. As per the State Bank of Pakistan (SBP), there are forty-five banks with more than 10,000 branches and 8000 ATMs. These large numbers of banks in Pakistan are now facing fierce competition with each other, and that leads to an increase in the offering of new products and services through Islamic banking, online and mobile banking from these banks. [23]. To improve service performance, banks look for additional marketing strategies to get the favorable attitude of the customers [24]. The findings of the current study would be helpful for the banks in how they can build up marketing strategies based on CSR and co-creation, and this empirical work will be of great concern for the marketing practitioners and banking executives.

The remaining section of the paper constitutes theoretical background and hypotheses development, the methodology, data analysis, and finally, discussion, and conclusion.

\section{Theoretical Background and Hypotheses Development}

\subsection{Corporate Social Responsibility and Customer Loyalty}

In today's highly competitive world, companies are facing multifaceted challenges. Customers are demanding new variants of the products at the lowest possible costs on one side, and competitors are trying to snatch market share through aggressive marketing. On the other hand, keeping the customer base intact is a matter of survival, and the most effective and cost-efficient way might be to increase the number of loyal customers and spread positive word of mouth through them. The relationship between CSR and customer loyalty is explained through the theory of social exchange. Blau [25] states that if a firm involves socially responsible behavior, then this creates generalized reciprocity. Eisingerich, 
et al. [26] suggested that the principle of general reciprocity can be used to explain the CSR activities carried out by companies on consumer behavior. CSR activities create generalized reciprocity as firms sometimes do not offer the direct benefit of CSR to their customers. Still, the customer as a member of society reciprocates these responsible activities [26]. CSR can influence and stimulate the positive relationship between the customer and the company and its products and services [27]. CSR has also constituted an ability to impact customer loyalty in different industries, such as hypermarkets and health insurance service brands in Spain $[7,28]$. A positive relationship between CSR and customer loyalty is found out by Khan et al. and Raza et al. [29] in the Pakistani banking industry. Likewise, CSR has a positive relationship with purchase intention and customer relationship intention [28]. Now there is a need to comprehend how and why CSR affects customer loyalty in Pakistan because it is an emerging and developing country with specific beliefs, cultures, and values, and this research may offer distinct results from studies conducted in developed countries. Based on the above theoretical and empirical evidence, we propose the following hypothesis:

Hypothesis H1. Corporate social responsibility significantly and positively affects customer loyalty.

\subsection{Corporate Social Responsibility Perceptions and Customer Company Identification}

$\mathrm{CCI}$ is a classic and affective variable but was not utilized very much in previous studies related to CSR and consumer behavior [30]. Grounded in the social identity theory, CCI assists in illuminating reasons through which individuals relate to the companies. Previous literature has explained that to start the identification process, customers need to understand critical corporate values and should feel a sense of connection and belonging with an organization, even if they are not the formal member of an organization [8]. Similarly, customers incline to ascribe themselves with those groups which they conceive socially responsible and distinctive from others. In the professional and business settings, customers who identify with a socially responsible company are more likely to endorse its products and services [31]. Previous studies have confirmed the positive relationship between CSR and CCI [32,33]. An organization with a good reputation of being socially responsible could help to fulfill customer self-definitional needs, thus positively affecting his/her identification with an organization. Customers' opinions about an organization's values can be strengthened by CSR initiatives of companies [32]. Based on the above arguments, we propose the following hypothesis:

Hypothesis H2. Corporate social responsibility significantly and positively affects customer-company identification.

\subsection{Customer-Company Identification and Customer Loyalty}

Loyalty has conventionally been described as a firm commitment and dedication of customers to repurchase the product or service despite any environmental influences or marketing efforts of companies and brands [34]. In the seminal work of Bhattacharya and Sen [35], it has been asserted that once a customer identifies with the company, then they show company favoring responses. Customers' positive in-role and extra-role behavior are just two types of these companies supporting responses. Identified customers tend to show the repurchase intention and loyalty behavior. In the banking sector, Fatma and Rahman [36] confirmed the positive association between CCI and purchase intention. Likewise, Pérez and Rodriguez del Bosque [37] and Moisescu, et al. [38] also confirmed that CCI positively and significantly affects the loyalty of the customers in the banking, telecom, and dairy product sectors. Therefore, the authors propose the following hypothesis:

Hypothesis H3. Customer company identification significantly and positively affects customer loyalty. 


\subsection{Corporate Social Responsibility and Co-Creation}

Customers nowadays are very demanding for unique and innovative experiences from companies to meet their personal needs and wants [19]. Co-creation explains this relationship between customers and companies. This concept is vast in scope and entails customer participation to involvement in the production process [19]. Prahalad and Ramaswamy [20] contend that co-creation is a customer-oriented approach, which allows a customer to participate in both product and service creation. Bank's CSR activities and co-creation can be best explained through the ethical values-driven marketing 3.0 paradigm. According to this paradigm, customers, just like companies, are also concerned to make this world a better place, guided by their ethical and moral values; customers purchase decisions depend on the sustainable product and ethical consumption. Customers consider responsible use and consumption as a preferred mode to search for solutions for their own needs [39]. Customers show affinity, trust, and a strong bond with those companies which exhibit environmental and social concern, equality, and security in their processes.

Environmental dynamic also plays a massive role in the value creation process between customers and organizations. Recurrent changes in the environment, such as changes in customer preference, the attrition of industry boundaries, changes to demographics and social values, government regulations, and technology adoption, are termed as environmental dynamics [40]. These ecological dynamics will pressurize companies to commit to their strategic decisions or face disaster [41]. On the same vein, socially responsible banks must adopt innovative solutions that are suitable to their changing situations. These environmental changes have also forced the banks to look for other ways to build collaborative relationships with their customers. Banks that can quickly adjust to environmental changes will be more adaptive to innovative practices as they apply to co-creation dynamics. In any industry, environmental dynamics such as technology adoption is a significant antecedent which positively affects the co-creation [41].

Banks' CSR activities related to co-creation are interactional [42]. According to Vitell (2015), CSR and co-creation are interlinked through two features: customers prefer to participate in those activities which give sustainable benefits through a positive impact on society and the environment; second, to avoid those practices which may harm the society and environment. Customers can enhance their self-esteem and pride by consuming the services of a socially responsible company since they feel they can contribute to the community and environment indirectly by doing it so [43].

Banks' engagement in CSR activities provides customers structured resources in the form of service knowledge and personal resources. Service knowledge comprises service quality, service delivery, and social support. Social support includes suggestions from bank employees, the empathy of the bank staff, while pride, positive emotions, and higher self-esteem come under personal resources [43]. So, when customers receive structured resources from a socially responsible company, they also become willing to invest their resources in behaviors that would be beneficial to a company, and co-creation is one form of those resources. Customers give feedback to companies about service quality, service culture, and suggestions to improve overall system design by engaging in the co-creation process [43]. The literature confirms the role of CSR in fostering customer citizenship behavior [8] and co-creation [7].

Hence, based on the above theoretical underpinnings and empirical evidence, we hypothesize that:

Hypothesis H4. Corporate social responsibility significantly and positively affects co-creation.

\subsection{Co-Creation and Customer Loyalty}

Customer loyalty is a customer's intention to repurchase the products and services and referrals to others [44]. Previous studies linked emotional variable (affective commitment) and rational variable (trust) to loyalty, but its relationship with the interactional valuable (co-creation) is not extensively researched and is still unclear [7]. Some studies investigate the relationship between co-creation and customer-related outcomes in different industry settings. Even as per the authors' knowledge, 
no research has been taken into consideration the relationship between co-creation and customer loyalty in the banking sector. Cossío-Silva, et al. [45] confirmed the positive relationship between co-creation and customer loyalty in personal care firms. In the context of brand communities, Kaufmann, et al. [46] proposed co-creation create loyalty through the mediation of brand trust. In the banking sector, Hosseini and Hosseini [47] show that involving customers in the co-creation process generates positive consumer behavior in the form of loyalty. According to findings from multiple settings, we hypothesize that:

Hypothesis H5. Co-creation significantly and positively affects customer loyalty.

\subsection{Customer-Company Identification and Co-Creation}

Service-dominant logic states that "customers are co-partners and co-producers of values, services, and skills" [48]. The customer is an operant source for co-creation, and CCI has a significant influence on the co-creating activities of the customers [5]. According to social identity theory, firm identification with a company leads to more social interaction between a company and customers, which leads to customer citizenship behavior [8,49]. Once a customer identifies with the company, then customers want to participate in co-creating activities through their involvement in feedback, product, and service design [35]. When customers perceive that companies conduct their businesses over and above the ethical and legal requirements and take care of different stakeholders, including society and environment, then their identification with a company increases, resulting in co-creation [5]. This line of discussion based on social identity theory and ethical values-driven marketing 3.0 paradigm leads to the expected positive relationship between $\mathrm{CCI}$ and co-creation behavior:

Hypothesis H6. Customer company identification significantly and positively affects co-creation.

\subsection{Mediating Role of Customer-Company Identification between CSR and Customer Loyalty}

There is still inadequate and little comprehension of the different paths that link CSR to customer loyalty [50]. CCI is one of those paths that link CSR to customer loyalty. Based on social identity theory, this concept is put forward by Bhattacharya and Sen [35], who asserted that to meet their self-definitional needs, customers identify themselves with a company. The firm that acts as socially responsible is more attractive for the customers to identify with [51]. Once customers identify with a firm, they not only indulge in the purchase process, but also show extra-role behavior in the form of loyalty, positive word of mouth, and citizenship behavior [52]. Few other studies have empirically confirmed the mediating role of CCI. A Study by Marin, Ruiz and Rubio [50] confirmed that CCI acts as a mediator between CSR and customer loyalty. Deng and $\mathrm{Xu}$ [51] also empirically proved the mediating role of CCI between purchase intention and word of mouth. Similarly, in the hospitality industry, the mediation of CCI between CSR and customer loyalty is confirmed by Martinez et al. [53]. Based on the above theoretical and empirical discussion, we postulate the following hypothesis:

Hypothesis H7. CCI mediates between customer perceptions of CSR and customer loyalty.

\subsection{Mediating Role of Co-Creation between CSR and Customer Loyalty}

Several theoretical and empirical considerations endorse the role of CSR as a critical motivator for co-creation. CSR, which takes into account the interest of different stakeholders, may strengthen the relationship between customers and the organizations as well as stimulate customers to co-create value with the organization in the light of service-dominant logic [5]. According to service-dominant logic, when companies view interactions with customers as being sustainable rather than transactional under CSR strategy, they better engage customers in value co-creation. Once customers engage in value 
co-creation behavior with the companies, then mutual bonds arise, which results in customer loyalty [1]. For example, Iglesias, Markovic, Bagherzadeh and Singh [7] concluded that when customers become aware of the CSR activities of a company, they become an active resource for a company through their participation behavior and this participation behavior leads to their loyalty. Based on the arguments mentioned above, we conclude that:

Hypothesis H8. Co-creation mediates the relationship between CSR and customer loyalty.

\subsection{Sequential Mediating Role of Customer-Company Identification and Co-Creation}

One aspect of this research is to test the sequential mediation of $\mathrm{CCI}$ and co-creation. According to social identity theory, customers want to relate with the companies to meet their self-definitional needs [35]. So, when a company involves in CSR activities and tries to maintain a healthy relationship with its stakeholders, then the identification process of the customers start [30]. CCI helps to explain the relationship between stakeholders and companies [54]. CCI is one of the pre-requisite for co-creation of customers with the companies, and a robust customer-company identification occurs when customers identify themselves with the companies [37]. Through this identification, customers can fulfill their needs, such as self-continuity, self-distinctiveness, and self-enhancement. This fulfillment of self-definitional requirements helps customers to actively participate in the interactive and innovative process [39]. Co-creation also requires customer orientation, meaning that firms and customers should have a closer relationship with each other [1]. Hence, based on the above theoretical foundation, the following hypothesis is proposed: Figure 1 shows the conceptual model of the study.

Hypothesis H9. Customer company identification and co-creation sequentially mediate between CSR and customer loyalty.

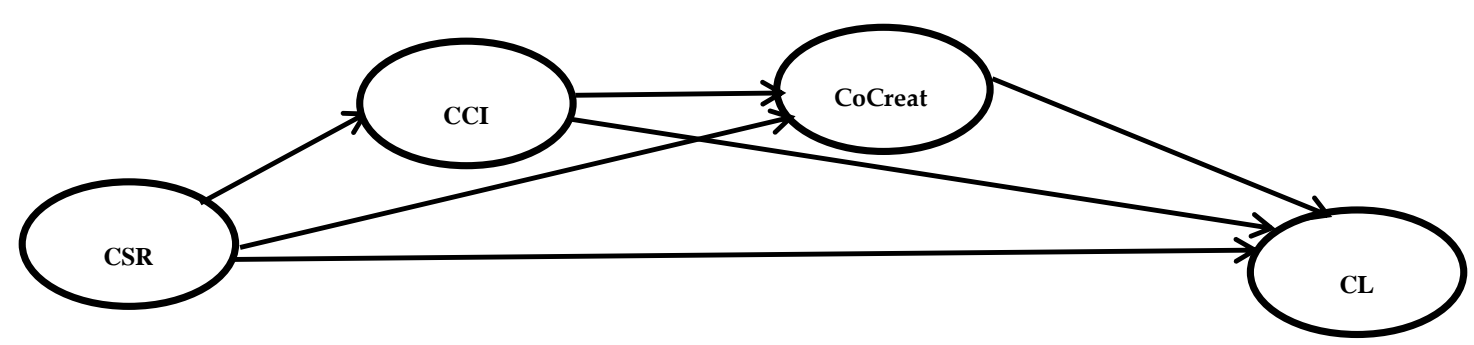

Figure 1. Conceptual model.

\section{Methodology}

\subsection{Research Design and Sample}

The proposed model is tested in the banking industry of Pakistan. Data were collected through field surveys in three big cities, i.e., Islamabad, Rawalpindi, and Lahore. Islamabad is the capital of Pakistan, while Rawalpindi is its neighboring city. Lahore is the second-largest city in Pakistan and also the capital of the largest province of Punjab. In total, 400 questionnaires were distributed, and 307 were returned, and after processing the information and concerning the social desirability bias, 280 valid questionnaires were used in the final data analysis. In our study, all those people who were above the age of 18 and had at least one bank account, for which they were the primary decision-makers at the time of answering the questionnaire, were regarded as banking customers. A multi-stage stratified sampling technique was applied to collect the data. In the first stage, banks were selected based on selection criteria that a bank should have more than 1000 branches with existence in all the provinces of Pakistan and also actively involved in the CSR activities. Four banks, namely the National Bank of Pakistan (NBP), Habib Bank Limited (HBL), United Bank Limited (UBL), and Muslim Commercial 
Bank Limited (MCB), met the criteria and were selected for further investigation. In the second stage, different residential and commercial areas of each city were randomly selected to collect the data from various branches of the banks. Data collectors visited different selected areas at different days of the week and different timings of a day to collect data from randomly selected customers. Respondents were contacted when they were exiting the bank branch or ATM service area. Approaching the customers in this way is consistent with the studies carried out by [23,55].

Those banks were chosen, which were actively involved in CSR activities. An explorative study was conducted before the field survey to search these banks. Considerable efforts were made to learn about the CSR activities of the selected banks and the way they communicate these CSR activities to their customers. The criteria applied to select the banks included, banks should have a separate web page of CSR on their official website, and banks should publish the CSR related news in print and electronic media and must illustrate their CSR activities in the annual reports explicitly indicating the amount of CSR investment. These chosen banks are the largest in the country and cover around $80 \%$ of the geographical areas of Pakistan. Moreover, data were collected from October 2019 to December 2019.

\subsection{Sample Profile}

The sample characteristics of the data are shown in Table 1. Most of the respondents in our research are male because Pakistan is a dominant male society, and it is challenging for the household women to visit banks for financial matters. Somehow, the authors managed to gather responses from 80 women. Moreover, data are deliberately collected from educated people because they have awareness about the social responsibility concept of banks.

Table 1. Sample profile.

\begin{tabular}{cccccc}
\hline & Frequency & \%age & Frequency & \%age \\
\hline Gender & & \multicolumn{5}{c}{ Income Level } \\
\hline Male & 200 & $71.4 \%$ & $<20,000$ & 7 & $2.5 \%$ \\
\hline Female & 80 & $28.6 \%$ & $21,000-40,000$ & 53 & $18.9 \%$ \\
\hline Age & 15 & $5.4 \%$ & $61,000-80,000$ & 63 & $27.9 \%$ \\
\hline 20 years or younger & 150 & $53.6 \%$ & $81,000-100,000$ & 29 & $10.4 \%$ \\
\hline $21-30$ & 50 & $17.9 \%$ & $100,000-120,000$ & 31 & $11.1 \%$ \\
\hline $31-40$ & 40 & $14.3 \%$ & Above 120,000 & 19 & $6.8 \%$ \\
\hline $41-50$ & 25 & $8.9 \%$ & Profession & & \\
\hline $51-60$ & & & Student & 33 & $11.8 \%$ \\
\hline Education & 32 & $11.4 \%$ & Businessmen & 67 & $23.9 \%$ \\
\hline High School & 123 & $43.9 \%$ & Govt. job & 91 & $32.5 \%$ \\
\hline Bachelor's degree & 102 & $36.4 \%$ & Private Job & 77 & $27.5 \%$ \\
\hline Master & 23 & $8.2 \%$ & Housewife & 12 & $4.3 \%$ \\
\hline PhD & & &
\end{tabular}

This study depends on the direct responses from customers for the collection of data, so social desirability bias (SDB) might be present in the survey [56,57]. Different steps were taken to manage and curtail the impact of SDB, as suggested by Grimm [57]. First, two authors were directly involved in the data collection process, and they first confirmed about knowledge of the CSR and also took their consent from customers and then proceeded with the questionnaires. Moreover, the previously recognized and empirically tested scales were employed for the constructs, and data were collected from different branches of the same banks in various residential and commercial areas of the selected cities. Furthermore, all items were reviewed by experts, including marketing professors and items 
of Independent Variable (IV) and Dependent Variable (DV) are separated from each other in the questionnaire survey.

\subsection{Common Method Variance (CMV)}

Similarly, to examine CMV, the method suggested by Kock [58] was employed. According to him, if the occurrence of Variance Inflation Factor (VIF) is greater than 3.3, then it is an indication that the model is contaminated with CMV and collinearity. However, in this study, all factor level VIFs resulting from full collinearity test are lower than the recommended threshold 3.3, considering the model is free from CMV. Therefore, CMV is not an issue in this study.

\subsection{Measurement Scales}

This study has used already established and validated scales for all the constructs in the proposed model, and responses are recorded by using seven points Likert scale. CSR perceptions were evaluated by the stakeholder-based approach suggested by Parez et al. [59]. The scale was taken as reflective formative in nature with 22 items and five dimensions: customers, shareholders, employees, community, and general dimension defining ethical and legal issues. The five aspects of CSR were formative, whereas items of those dimensions were reflective. Customer-company identification measured as a reflective construct through four questions scale by Mael and Ashforth [60]. Customer loyalty is measured by a scale adapted from Dagger et al. [61] with three items. Co-creation has three questions, and the scale is taken from Dong et al. and Ho and Ganesan [62,63], where both co-creation and customer loyalty are reflective constructs.

\section{Analysis and Results}

\subsection{Evaluation of Measurement Model}

To measure the reliability and validity of the instrument and to test the hypotheses, WarpPLS 6 [64] is used in this study. Partial least structure equation modeling (PLS-SEM) is a variance-based approach that uses total variance to estimate the parameters and its consistent with the studies [65-67]. PLS-SEM is preferred in this study due to the following reasons, as explained by Hair et al. [68].

1. The latest guidelines on the use of PLS-SEM have proved its superiority in assessing mediation analysis.

2. When the objective of the study is to predict, then PLS-SEM is preferable.

3. Lastly, constructs used for CSR in this study are formative, and PLS-SEM is better in investigating the formative constructs.

Assessing first-order reflective measurement model

To evaluate the measurement model, the first task is to determine the item loadings, where a value of 0.70 or more is needed to confirm the reliability of the indicators [65]. Table 2 assures the reliability of the item of the constructs as all the values are more than the benchmark of 0.7. Next is to measure the internal consistency, for this purpose, Cronbach $\alpha$ and composite reliability (CR) are analyzed. Values for Cronbach $\alpha$ and CR should be more than 0.7 [65]. Table 2 shows the values of Cronbach $\alpha$ and CR, having all values above the acceptable range. The third step is to measure the convergent validity of each construct [65]. The average variance extracted (AVE) is used to evaluate convergent validity. The threshold value for AVE is 0.5 , and Table 2 also shows the AVE values, confirming the convergent validity. 
Table 2. Reliability, validity, and quality indicators of first-order constructs.

\begin{tabular}{|c|c|c|c|c|c|c|c|}
\hline Construct & Item & Loading & $\alpha$ & CR & AVE & $\mathbf{R}^{2}$ & $\mathrm{Q}^{2}$ \\
\hline \multirow{4}{*}{ Customer Loyalty } & & & 0.947 & 0.966 & 0.904 & 0.706 & 0.706 \\
\hline & CL1 & 0.951 & & & & & \\
\hline & CL2 & 0.958 & & & & & \\
\hline & CL3 & 0.942 & & & & & \\
\hline \multirow{4}{*}{ Co-creation } & & & 0.936 & 0.959 & 0.887 & 0.547 & 0.546 \\
\hline & $\mathrm{CO} 1$ & 0.925 & & & & & \\
\hline & $\mathrm{CO} 2$ & 0.956 & & & & & \\
\hline & $\mathrm{CO} 3$ & 0.943 & & & & & \\
\hline \multirow{5}{*}{ Customer-Company Identification } & & & 0.925 & 0.947 & 0.817 & 0.474 & 0.475 \\
\hline & CCI1 & 0.893 & & & & & \\
\hline & $\mathrm{CCI} 2$ & 0.882 & & & & & \\
\hline & $\mathrm{CCI} 3$ & 0.929 & & & & & \\
\hline & CCI4 & 0.912 & & & & & \\
\hline \multirow{6}{*}{ CSR-Customer } & & & 0.926 & 0.944 & 0.771 & & \\
\hline & $\mathrm{C} 1$ & 0.857 & & & & & \\
\hline & $\mathrm{C} 2$ & 0.883 & & & & & \\
\hline & $\mathrm{C} 3$ & 0.912 & & & & & \\
\hline & $\mathrm{C} 4$ & 0.892 & & & & & \\
\hline & C5 & 0.845 & & & & & \\
\hline \multirow{4}{*}{ CSR-Shareholder } & & & 0.871 & 0.921 & 0.796 & & \\
\hline & S1 & 0.884 & & & & & \\
\hline & S2 & 0.899 & & & & & \\
\hline & S3 & 0.893 & & & & & \\
\hline \multirow{6}{*}{ CSR-Employees } & & & 0.916 & 0.938 & 0.751 & & \\
\hline & E1 & 0.795 & & & & & \\
\hline & E2 & 0.903 & & & & & \\
\hline & E3 & 0.895 & & & & & \\
\hline & $\mathrm{E} 4$ & 0.893 & & & & & \\
\hline & E5 & 0.841 & & & & & \\
\hline \multirow{7}{*}{ CSR-Community } & & & 0.928 & 0.944 & 0.737 & & \\
\hline & Com1 & 0.842 & & & & & \\
\hline & Com2 & 0.847 & & & & & \\
\hline & Com3 & 0.833 & & & & & \\
\hline & Com 4 & 0.896 & & & & & \\
\hline & Com5 & 0.873 & & & & & \\
\hline & Com6 & 0.857 & & & & & \\
\hline \multirow{4}{*}{ CSR-General } & & & 0.920 & 0.949 & 0.862 & & \\
\hline & G1 & 0.922 & & & & & \\
\hline & G2 & 0.932 & & & & & \\
\hline & G3 & 0.931 & & & & & \\
\hline
\end{tabular}


The fourth step is to assess the discriminant validity, which is the extent to which a construct is different from the other constructs [65]. To assess discriminant validity, an approach by Fornell and Larcker [69] is employed, which requires a higher square root value of AVE of any construct than its correlation with all other constructs. Table 3 shows the discriminant validity of the first order measurement model, where all the values in the diagonal are the square root of AVE of respective constructs and shown in bold. All values confirm the condition of the discriminant validity.

Table 3. Discriminant validity of the first-order measurement model.

\begin{tabular}{|c|c|c|c|c|c|c|c|c|}
\hline & CustLoy & CSR_Cus & CSR_Shr & CSR_Emp & CSR_Com & CSR_Gen & CCI & CoCreat \\
\hline CustLoy & 0.951 & & & & & & & \\
\hline CSR_Cus & 0.68 & 0.878 & & & & & & \\
\hline CSR_Shr & 0.528 & 0.742 & 0.892 & & & & & \\
\hline CSR_Emp & 0.64 & 0.715 & 0.615 & 0.866 & & & & \\
\hline CSR_Com & 0.642 & 0.669 & 0.612 & 0.762 & 0.859 & & & \\
\hline CSR_Gen & 0.665 & 0.723 & 0.7 & 0.705 & 0.737 & 0.928 & & \\
\hline $\mathrm{CCI}$ & 0.769 & 0.577 & 0.483 & 0.56 & 0.633 & 0.632 & 0.904 & \\
\hline CoCreat & 0.796 & 0.712 & 0.595 & 0.63 & 0.66 & 0.738 & 0.739 & 0.942 \\
\hline
\end{tabular}

CustLoy= Customer Loyalty; CSR_Cus= CSR Customer; CSR_Shr $=$ CSR Shareholder; CSR_Emp $=$ CSR Employees; CSR_Com= CSR Community; CSR_Gen= CSR General; CCI= Customer Company Identification; CoCreat $=$ Co-Creation.

\subsection{Assessing the Formative Measurement Model}

PLS-SEM is preferable when a conceptual model contains the formative constructs [68]. To evaluate the formative constructs, indicator collinearity, indicator weights, and statistical significance are assessed [65]. The variance inflation factor (VIF) is used to measure the collinearity. The value of 5 or above indicates collinearity issues among the predictor constructs [65]. VIF values of the formative construct (CSR) are given in Table 4 , and all of these values are below 5 , thus indicating no collinearity issues. In the second step, indicator weights and statistical significance are assessed. Table 4 also presents the outer weights and their p-values for the constructs of customers, shareholders, employees, and community and general dimensions confirming their significance. Table 5 shows the discriminant validity of the second-order measurement model. WarpPLS 6 also calculates full collinearity by tracking any constructs vertical and lateral collinearity concerning other constructs, and this value also needs to be less than $5[70,71]$.

Table 4. Second-order formative construct measurement model.

\begin{tabular}{cccccc}
\hline $\begin{array}{c}\text { Second-Order } \\
\text { Construct }\end{array}$ & $\begin{array}{c}\text { First-Order } \\
\text { Constructs }\end{array}$ & Weights & $p$-Value & VIF & $\begin{array}{c}\text { Full } \\
\text { Collinearity }\end{array}$ \\
\cline { 2 - 5 } & CSR-Customer & 0.233 & $<0.01$ & 3.126 \\
\cline { 2 - 5 } $\begin{array}{c}\text { Corporate Social } \\
\text { Responsibility (CSR) }\end{array}$ & CSR-Shareholder & 0.221 & $<0.01$ & 2.554 \\
\cline { 2 - 6 } & CSR-Employees & 0.23 & $<0.01$ & 2.997 \\
\cline { 2 - 6 } & CSR-Community & 0.229 & $<0.01$ & 2.984 \\
\cline { 2 - 5 } & CSR-General & 0.234 & $<0.01$ & 3.077 \\
\hline
\end{tabular}


Table 5. Discriminant validity of the second-order measurement model.

\begin{tabular}{ccccc}
\hline & CusLoyl & CSR & CCI & CoCreat \\
\hline CusLoyl & 0.951 & & & \\
\hline CSR & 0.725 & 0.871 & & \\
\hline CCI & 0.769 & 0.664 & 0.904 & \\
\hline CoCreat & 0.796 & 0.767 & 0.739 & 0.942 \\
\hline
\end{tabular}

CustLoy= Customer Loyalty; CSR= Corporate Social Responsibility; CCI= Customer Company Identification; $\mathrm{CoCre}=\mathrm{Co}-\mathrm{Creation}$.

\subsection{Evaluating Structural Model}

To estimate the structural model coefficient of determination $\left(R^{2}\right)$, the statistical significance of the path coefficients $(\beta)$, the blindfolding based cross-validated redundancy measure $\left(Q^{2}\right)$, and effect size $\left(\mathrm{f}^{2}\right)$ are used. The $\mathrm{R}^{2}$ measure is the variance explained in each of the endogenous constructs, and therefore also called the model's explanatory power. The $R^{2}$ value for customer loyalty is 0.762 , and Table 2 shows the $R^{2}$ values of all the endogenous constructs. To assess how the removal of a predictor impacts endogenous construct's $R^{2}$, the effect size represented by $\mathrm{f}^{2}$ is used. Table 6 shows the value of $\mathrm{f}^{2}$ for all the endogenous constructs, and here effect size from CSR to customer loyalty shows the weakest value of 0.144 , while the strongest is between CSR and CCI with a value of 0.44 . Another method to assess the PLS path model predictive accuracy is by calculating the $\mathrm{Q}^{2}$ value [65]. As per guidelines, the value of $Q^{2}$ should be higher than 0 for specific endogenous constructs to indicate the predictive accuracy of the structural model for that construct. Table 2 provides $Q^{2}$ values of all the endogenous constructs.

Table 6. Hypotheses results and effect size.

\begin{tabular}{ccccc}
\hline Hypothesized Path & Path Coefficient & $\boldsymbol{p}$-Value & $\mathbf{f}^{\mathbf{2}}$ & Decision \\
\hline CSR ->Customer Loyalty & 0.195 & $<0.01$ & 0.142 & Supported \\
\hline CSR ->CCI & 0.664 & $<0.01$ & 0.440 & Supported \\
\hline CCI ->Customer Loyalty & 0.360 & $<0.01$ & 0.275 & Supported \\
\hline CSR ->Co-creation & 0.494 & $<0.01$ & 0.378 & Supported \\
\hline Co-creation ->Customer Loyalty & 0.380 & $<0.01$ & 0.304 & Supported \\
\hline CCI ->Co-creation & 0.412 & $<0.01$ & 0.305 & Supported \\
\hline
\end{tabular}

\subsection{Hypotheses Testing}

Hypotheses testing results of direct paths are shown in Table 6, and all the direct paths are supported. To evaluate results, the bootstrapping method is applied to test the strength and significance of the hypothesized path coefficients. Path coefficients ( $\beta$-values) provide the empirical support for the direct effects conceived in our model at a $5 \%$ significance level.

\subsection{Multiple and Sequential Mediation Test}

The mediating effect of co-creation and $\mathrm{CCI}$ is investigated through a process described by Nitzl et al. [72]. The bootstrap method is applied to obtain information about the significance of the indirect paths [73].

Figure 2 shows the total effect and its significance value $(\beta=0.73, p$-value $<0.01)$ between CSR and customer loyalty along with its $\mathrm{R}^{2}$ value (0.53). After performing mediation analysis, results shown in Table 7 , customer loyalty remains significant at a confidence interval of $95 \%$ in the presence of both mediators in the model $(\beta=0.19, p$-value $<0.01)$. Although the intensity of the direct path reduces, it remains significant. The calculation of the indirect effects shows that mediators such as CCI (a1b1), 
and co-creation $\left(\mathrm{a}_{2} \mathrm{~b}_{2}\right)$ partially mediated the relationship between CSR activities and customer loyalty. Similarly, Figure 3 shows the sequential mediating effect of CCI and co-creation on customer loyalty as well. Thus, confirming the partial sequential mediating effect of CCI and co-creation between CSR and customer loyalty confirms the hypothesis H9.

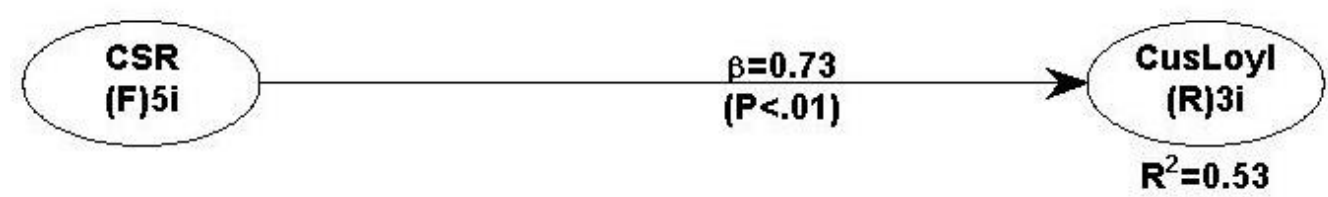

Figure 2. The total effect of CSR on customer loyalty.

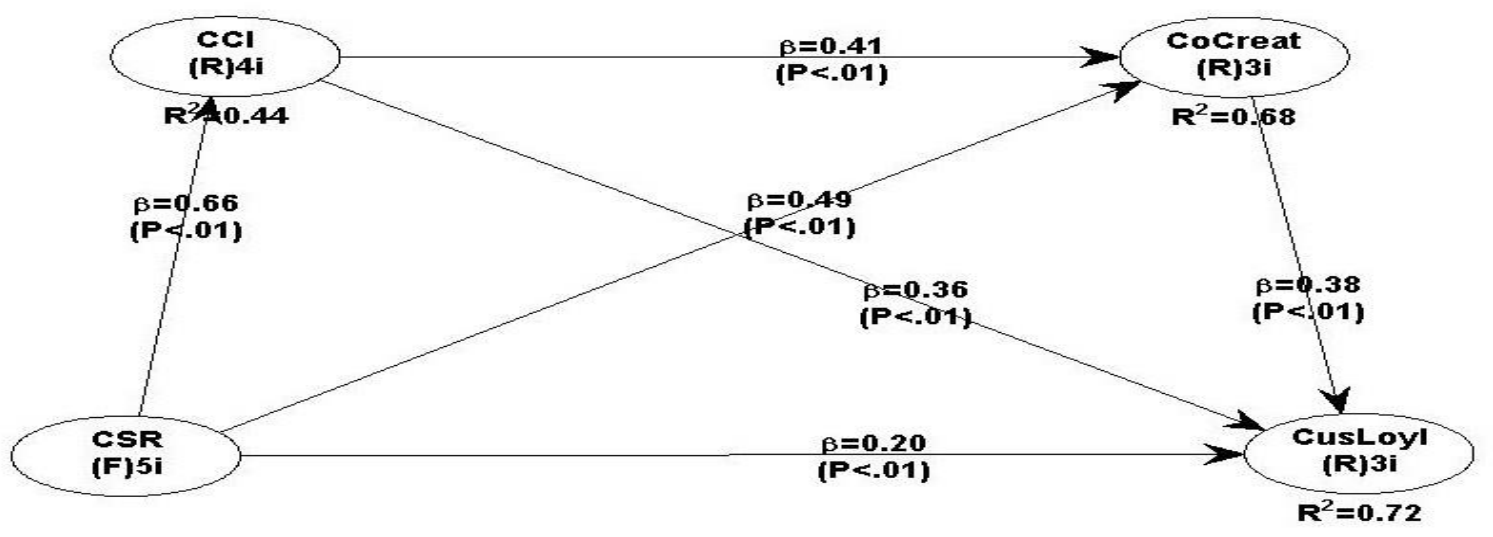

Figure 3. Second-order structural model result.

Table 7. Indirect effect results.

\begin{tabular}{|c|c|c|c|c|}
\hline Hypothesized Path & Path Coefficient & $p$-Value & $\mathbf{f}^{2}$ & Decision \\
\hline CSR $->$ CCI $->$ CusLoyl $=\left(a_{1} b_{1}\right)$ & 0.237 & $<0.01$ & 0.172 & Supported \\
\hline CSR $->$ Co-creat $->$ CusLoyl $=\left(\mathrm{a}_{2} \mathrm{~b}_{2}\right)$ & 0.292 & $<0.01$ & 0.212 & Supported \\
\hline CSR $->$ CCI $->$ Co-creat- $>$ CusLoyl $=\left(a_{1} a_{3} b_{2}\right)$ & 0.104 & 0.001 & 0.075 & Supported \\
\hline
\end{tabular}

\section{Discussion and Conclusions}

The main goal of the study is to measure the effect of banks' CSR activities on customer loyalty directly and through intervening variables, i.e., CCI and co-creation. The results of this research confirm the previous literature that CSR has a direct and positive effect on customer's loyalty [23,74-76]. Findings reveal that customers in Pakistan behave in a similar pattern, as customers in developed countries. Consumer culture theory [77] supports the findings of this study. According to this theory, the Internet serves as a medium for convergence of the customers' behavior, as a technological breakthrough has made it easy for everyone to access information from any part of the world, and consumers around the globe somehow think in a standardized way. That is why customers align their identities based on the consumer-driven global economy, which is highly dependent on information technology. Therefore, customers in Pakistan behave in the same way as customers in other parts of the developed world. The second reason is that the banks in Pakistan offer almost standardized service quality, same interest rate, and the same technological ease to which customers seek no difference in the products and services which they offer. In this way, customers' lower-order needs are already met by standardized service quality and electronic service quality, such as mobile apps, self-service technologies, and traditional customer-employee interaction. So, to fulfill their higher-order needs, 
customers show an affinity to those banks who consider stakeholders' concerns in their strategic plans. The customer nowadays accentuates more on ethical consumption, environment-friendly products, complaint handling procedures, and fair practices. In other words, the customer's choice of banks is increasingly dependent on the extent to which they permit to fulfill their higher-order needs for social, environmental, and economic justice [39]. While trying to fulfill these needs, decision-makers need to keep in mind the awareness level of its customers about the organization's CSR claims and their actual practices. Customers will prefer to believe in and associate themselves with those organizations which have long CSR history, more local needs focused CSR activities, and are being performed without any irregularity or accidents $[10,16]$.

Second objective deals with the investigation of the mediating effect of $\mathrm{CCI}$ and co-creation between CSR and customer loyalty. Both CCI and co-creation mediate between CSR and customer loyalty and explain the mechanism through which CSR affects customer loyalty. This study confirms the positive and significant impact of $\mathrm{CCI}$ on co-creation in a way that customers start identifying themselves with their banks. Then, they contribute to the bank through their feedback and involvement. Identified customers positively contribute to the new product and service development and design processes. This identification leads customers to participatory behavior, and when banks value their co-creation, a sense of ownership increases among the customers, which leads to favorable company response in the form of their loyalty.

Additionally, this study also confirms the sequential mediating effect of $\mathrm{CCI}$ and co-creation between CSR and customer loyalty, and this finding can be explained through the social identity theory. According to this theory, customers are more inclined towards those companies which have a positive CSR reputation [78,79]. Moreover, customers also desire the relationship with competent, proficient, and highly capable firms to satisfy the need for self-enhancement and self-distinctiveness [35]. Thereby, the customers must identify themselves with the bank for exhibiting loyalty behavior; without identification, loyalty cannot be formed with the banks. According to the findings of this research, the socially responsible behavior of the banks in Pakistan positively affects the co-creation of the customers. Banks throw signals to customers by participating in socially responsible activities where they value customers and embrace co-creation [7]. Through these CSR activities, banks also try to stir up the notion of strategic partnership through both customers and employees who jointly define a beneficial solution for both parties. In short, CSR creates identification among the customers, and these identified customers become more open to companies and listen to them and participate through innovative ideas through their opinions and positive feedback. Thus, CSR and CCI enable customers to co-create with the banks, which, as a result, enhances their loyalty.

\section{Theoretical and Managerial Implications}

First, this study confirms the role of CSR in creating customer loyalty in the banking industry of Pakistan. That is, when companies genuinely invest in CSR activities, they make every effort to generate social benefits for their stakeholders, including customers, employees, and the environment. Customers also support the companies through their positive behavior. Investment in CSR ensures that banks engage in more philanthropic work and consider the stakeholders' interest as their priority. In this way, they connect with the customers emotionally through the identification process, which eventually leads to loyalty.

Similarly, CSR enhances the co-creation of the customers, a legitimate approach to CSR by the banks, motivates customers to engage in dialogue and participatory behavior, and customers tend to provide more significant input regarding product and service quality designs [7]. CSR of the banks gives customers reasons to identify with the banks rightly; as a result, their self-esteem and pride increases, consequently motivating them to go beyond their usual role behavior. Moreover, social identity theory adds to the power of the ethical values-driven marketing 3.0 paradigm in explaining the relationship between CSR and customer co-creation. 
In addition to the theoretical contribution, this research contains some critical implications for banking executives. If banking executives want to derive the loyalty of the customers through CSR, then they need to engage with the customers. Banks need to promote a dialogue with the customers regarding new product and service development, and innovation-related strategies. Banks can use co-creation as a tool to enhance customers' participatory behavior in designing the bank's loans, their retirement plans, car leasing, and investment plans. In this way, banks can easily outsource innovation through the participatory behavior of the customers.

The literature on CSR proposes that companies should make it a priority to have a dialogue with customers [7]. Our study also supports this fact that when companies understand the needs of the customers and involve them in the co-creation process, then their loyalty enhances. Moreover, socially responsible activities not only provide the platform to customers to identify with the organization but also this identification leads to customers' participatory behavior. So, banks should build this identification through CSR-related initiatives as this kind of identification is much stronger than other factors [35]. CSR strategy of the banks should be translated into those actions which are correctly oriented for different stakeholders such as employee's personal growth, customer complaint handling procedures, following ethical and legal responsibilities, and working towards a better environment and community.

Lastly, banks should work on providing the culture that should welcome and appreciate the customers' participation and recognizes their expertise and knowledge. Furthermore, banks should have a strategic kind of relationship with the customers based on mutual trust and more robust identification. Banks should consider them as innovative strategic partners. This approach to co-creation has the highest potential to translate CSR practices into customer loyalty.

\section{Limitations and Future Research}

Like every other study, this research also has some limitations. First, this research is restricted to the banking sector only, and future studies can be conducted to other services sectors such as hospitality and tourism. Moreover, future studies can also consider the manufacturing industry and compare their results with the service industries. Second, this research is the only representative of the Pakistani population, and results cannot be generalized to all developing countries. Besides, as customers from different cultural backgrounds assess CSR differently, this kind of research in other developing counties may have some useful insights. So, it is recommended to replicate this research in other developing countries to increase the research generalizability. Furthermore, a similar study can be conducted to find out the intervening role of environmental dynamics in Pakistan and some other developing countries as well.

This study used cross-sectional data with stratified sampling, and further research can be conducted through longitudinal data and other sampling techniques. Some new variables, like customer commitment, satisfaction, and perceived service quality, can be added to structure a more comprehensive and complete framework. Finally, future studies can also consider the moderating effect of leadership style on the relationship between CSR and co-creation, as servant leadership and transformational leadership may have some impact on CSR and co-creation relationship. Furthermore, demographic variables such as age, gender, and education can also be used as a moderator to check the effect of these demographics on CSR-loyalty relationships.

Author Contributions: A.R. conceived and designed the study; A.R., N.A.F., and M.K.I. collected data; A.S., A.R., and the U.S. performed the data analysis and drafted the paper; A.R. and A.S. wrote the first draft; and U.S, I.S., N.A.F., and M.K.I. substantially revised the manuscript. All authors have read and agreed to the published version of the manuscript.

Funding: This research received no external funding.

Conflicts of Interest: The authors declare no conflict of interest. 


\section{References}

1. Cambra-Fierro, J.; Pérez, L.; Grott, E. Towards a co-creation framework in the retail banking services industry: Do demographics influence? J. Retail. Consum. Serv. 2017, 34, 219-228. [CrossRef]

2. Yeh, Y.-P. Corporate social responsibility and service innovation on customer loyalty: An empirical investigation in wealth management services. Int. J. Bank Mark. 2015, 33, 823-839. [CrossRef]

3. Baskentli, S.; Sen, S.; Du, S.; Bhattacharya, C. Consumer reactions to corporate social responsibility: The role of CSR domains. J. Bus. Res. 2019, 95, 502-513. [CrossRef]

4. Li, Y.; Liu, B.; Huan, T.-C.T. Renewal or not? Consumer response to a renewed corporate social responsibility strategy: Evidence from the coffee shop industry. Tour. Manag. 2019, 72, 170-179. [CrossRef]

5. Luu, T.T. CSR and Customer Value Co-creation Behavior: The Moderation Mechanisms of Servant Leadership and Relationship Marketing Orientation. J. Bus. Ethics 2019, 155, 379-398. [CrossRef]

6. Ahmed, I.; Nazir, M.S.; Ali, I.; Nurunnabi, M.; Khalid, A.; Shaukat, M.Z. Investing In CSR Pays You Back in Many Ways! The Case of Perceptual, Attitudinal and Behavioral Outcomes of Customers. Sustainability 2020, 12, 1158. [CrossRef]

7. Iglesias, O.; Markovic, S.; Bagherzadeh, M.; Singh, J.J. Co-creation: A key link between corporate social responsibility, customer trust, and customer loyalty. J. Bus. Ethics 2018, 1-16. [CrossRef]

8. Hur, W.M.; Kim, H.; Kim, H.K. Does customer engagement in corporate social responsibility initiatives lead to customer citizenship behaviour? The mediating roles of customer-company identification and affective commitment. Corp. Soc. Responsib. Environ. Manag. 2018, 25, 1258-1269. [CrossRef]

9. Castro-González, S.; Bande, B.; Fernández-Ferrín, P.; Kimura, T. Corporate social responsibility and consumer advocacy behaviors: The importance of emotions and moral virtues. J. Clean. Prod. 2019, 231, 846-855. [CrossRef]

10. Vanhamme, J.; Grobben, B. “Too good to be true!". The effectiveness of CSR history in countering negative publicity. J. Bus. Ethics 2009, 85, 273. [CrossRef]

11. Parguel, B.; Benoît-Moreau, F.; Larceneux, F. How sustainability ratings might deter 'greenwashing': A closer look at ethical corporate communication. J. Bus. Ethics 2011, 102, 15. [CrossRef]

12. Shim, K.; Yang, S.-U. The effect of bad reputation: The occurrence of crisis, corporate social responsibility, and perceptions of hypocrisy and attitudes toward a company. Public Relat. Rev. 2016, 42, 68-78. [CrossRef]

13. Foreh, M.R.; Grier, S. When is honesty the best policy? The effect of stated company intent on consumer skepticism. J. Consum. Psychol. 2003, 13, 349-356. [CrossRef]

14. Pope, S.; Wæraas, A. CSR-washing is rare: A conceptual framework, literature review, and critique. J. Bus. Ethics 2016, 137, 173-193. [CrossRef]

15. Osakwe, C.N.; Yusuf, T.O. CSR: A roadmap towards customer loyalty. Total Qual. Manag. Bus. Excell. 2020, 1-17. [CrossRef]

16. Fatma, M.; Ruiz, A.P.; Khan, I.; Rahman, Z. The effect of CSR engagement on eWOM on social media. Int. J. Organ. Anal. 2020. [CrossRef]

17. Grott, E.M.; Cambra-Fierro, J.; Perez, L.; Yani-de-Soriano, M. How cross-culture affects the outcomes of co-creation. Eur. Bus. Rev. 2019, 31, 544-566. [CrossRef]

18. Markovic, S.; Bagherzadeh, M. How does breadth of external stakeholder co-creation influence innovation performance? Analyzing the mediating roles of knowledge sharing and product innovation. J. Bus. Res. 2018, 88, 173-186. [CrossRef]

19. Mainardes, E.W.; Teixeira, A.; da Silveira Romano, P.C. Determinants of co-creation in banking services. Int. J. Bank Mark. 2017, 35, 187-204. [CrossRef]

20. Prahalad, C.K.; Ramaswamy, V. Co-creation experiences: The next practice in value creation. J. Interact. Mark. 2004, 18, 5-14. [CrossRef]

21. Beckerolsen, K.L.; Cudmore, B.A.; Hill, R.P. The impact of perceived corporate social responsibility on consumer behavior. J. Bus. Res. 2006, 59, 46-53. [CrossRef]

22. Arli, D.I.; Lasmono, H.K. Consumers' perception of corporate social responsibility in a developing country. Int. J. Consum. Stud. 2010, 34, 46-51. [CrossRef]

23. Khan, Z.; Ferguson, D.; Perez, A. Customer responses to CSR in the Pakistani banking industry. Int. J. Bank Mark. 2015, 33, 471-493. [CrossRef] 
24. Poolthong, Y.; Mandhachitara, R. Customer expectations of CSR, perceived service quality and brand effect in Thai retail banking. Int. J. Bank Mark. 2009, 27, 408-427. [CrossRef]

25. Blau, P. Exchange and Power in Social Life; JohnWiley and Sons: New York, NY, USA, 1964.

26. Eisingerich, A.B.; Rubera, G.; Seifert, M.; Bhardwaj, G. Doing good and doing better despite negative information?: The role of corporate social responsibility in consumer resistance to negative information. J. Serv. Res. 2011, 14, 60-75. [CrossRef]

27. Uhlig, M.R.H.; Mainardes, E.W.; Nossa, V. Corporate social responsibility and consumer's relationship intention. Corp. Soc. Responsib. Environ. Manag. 2020, 27, 313-324. [CrossRef]

28. Cuesta-Valiño, P.; Rodríguez, P.G.; Núñez-Barriopedro, E. The impact of corporate social responsibility on customer loyalty in hypermarkets: A new socially responsible strategy. Corp. Soc. Responsib. Environ. Manag. 2019, 26, 761-769. [CrossRef]

29. Raza, A.; Bhutta, U.S.; Iqbal, M.K.; Faraz, N.A. Corporate social responsibility and customer loyalty: A mediating role of trust. Eur. J. Bus. Soc. Sci. 2018, 7, 43-50.

30. Martinez, P.L.; Bosque, I.R.D. CSR and customer loyalty: The roles of trust, customer identification with the company and satisfaction. Int. J. Hosp. Manag. 2013, 35, 89-99. [CrossRef]

31. Fatma, M.; Khan, I.; Rahman, Z. CSR and consumer behavioral responses: The role of customer-company identification. Asia Pac. J. Mark. Logist. 2018, 30, 460-477. [CrossRef]

32. Su, L.; Swanson, S.R.; Hsu, M.; Chen, X. How does perceived corporate social responsibility contribute to green consumer behavior of Chinese tourists. Int. J. Contemp. Hosp. Manag. 2017, 29, 3157-3176. [CrossRef]

33. Huang, M.-H.; Cheng, Z.-H.; Chen, I.-C. The importance of CSR in forming customer-company identification and long-term loyalty. J. Serv. Mark. 2017, 31, 63-72. [CrossRef]

34. Oliver Richard, L. Satisfaction: A Behavioral Perspective on the Consumer; Irwin-McGraw-Hill: New York, NY, USA, 1997.

35. Bhattacharya, C.B.; Sen, S. Consumer-company identification: A framework for understanding consumers' relationships with companies. J. Mark. 2003, 67, 76-88. [CrossRef]

36. Fatma, M.; Rahman, Z. Consumer responses to CSR in Indian banking sector. Int. Rev. Public Nonprofit Mark. 2016, 13, 203-222. [CrossRef]

37. Pérez, A.; Rodriguez del Bosque, I. Corporate social responsibility and customer loyalty: Exploring the role of identification, satisfaction and type of company. J. Serv. Mark. 2015, 29, 15-25. [CrossRef]

38. Moisescu, O.I.; Gică, O.A.; Müller, V.O.; Müller, C.A. Can Corporate Fairness towards Public Authorities Enhance Customer Loyalty? A Multi-Sectorial Investigation in a Developing Country. Sustainability 2020, 12, 187. [CrossRef]

39. Martínez-Cañas, R.; Ruiz-Palomino, P.; Linuesa-Langreo, J.; Blázquez-Resino, J.J. Consumer participation in co-creation: An enlightening model of causes and effects based on ethical values and transcendent motives. Front. Psychol. 2016, 7, 793. [CrossRef]

40. Ge, J.; Xu, H.; Pellegrini, M.M. The effect of value co-creation on social enterprise growth: Moderating mechanism of environment dynamics. Sustainability 2019, 11, 250. [CrossRef]

41. Chen, J.-S.; Kerr, D.; Chou, C.Y.; Ang, C. Business co-creation for service innovation in the hospitality and tourism industry. Int. J. Contemp. Hosp. Manag. 2017, 29, 1522-1540. [CrossRef]

42. Singh, J.; Brady, M.; Arnold, T.; Brown, T. The emergent field of organizational frontlines. J. Serv. Res. 2017, 20, 3-11. [CrossRef]

43. Tuan, L.T.; Rajendran, D.; Rowley, C.; Khai, D.C. Customer value co-creation in the business-to-business tourism context: The roles of corporate social responsibility and customer empowering behaviors. J. Hosp. Tour. Manag. 2019, 39, 137-149. [CrossRef]

44. Markovic, S.; Iglesias, O.; Singh, J.J.; Sierra, V. How does the perceived ethicality of corporate services brands influence loyalty and positive word-of-mouth? Analyzing the roles of empathy, affective commitment, and perceived quality. J. Bus. Ethics 2018, 148, 721-740. [CrossRef]

45. Cossío-Silva, F.-J.; Revilla-Camacho, M.-Á.; Vega-Vázquez, M.; Palacios-Florencio, B. Value co-creation and customer loyalty. J. Bus. Res. 2016, 69, 1621-1625. [CrossRef]

46. Kaufmann, H.R.; Loureiro, S.M.C.; Manarioti, A. Exploring behavioural branding, brand love and brand co-creation. J. Prod. Brand Manag. 2016, 25, 516-526. [CrossRef]

47. Hosseini, M.H.; Hosseini, V.S. The Impact of Co-Production on Customer Loyalty in Banking Services: A Case of Saman Bank. Iran. J. Manag. Stud. 2013, 6, 105-129. [CrossRef] 
48. Vargo, S.L.; Lusch, R.F. The four service marketing myths: Remnants of a goods-based, manufacturing model. J. Serv. Res. 2004, 6, 324-335. [CrossRef]

49. Dutton, J.E.; Dukerich, J.M.; Harquail, C.V. Organizational images and member identification. Adm. Sci. Q. 1994, 39, 239-263. [CrossRef]

50. Marin, L.; Ruiz, S.; Rubio, A. The role of identity salience in the effects of corporate social responsibility on consumer behavior. J. Bus. Ethics 2009, 84, 65-78. [CrossRef]

51. Deng, X.; Xu, Y. Consumers' responses to corporate social responsibility initiatives: The mediating role of consumer-company identification. J. Bus. Ethics 2017, 142, 515-526. [CrossRef]

52. Ahearne, M.; Bhattacharya, C.B.; Gruen, T. Antecedents and consequences of customer-company identification: Expanding the role of relationship marketing. J. Appl. Psychol. 2005, 90, 574. [CrossRef] [PubMed]

53. Martínez, P.; Pérez, A.; Rodríguez del Bosque, I. Measuring corporate social responsibility in tourism: Development and validation of an efficient measurement scale in the hospitality industry. J. Travel Tour. Mark. 2013, 30, 365-385. [CrossRef]

54. Keh, H.T.; Xie, Y. Corporate reputation and customer behavioral intentions: The roles of trust, identification and commitment. Ind. Mark. Manag. 2009, 38, 732-742. [CrossRef]

55. Shah, S.S.A.; Khan, Z. Corporate social responsibility: A pathway to sustainable competitive advantage? Int. J. Bank Mark. 2019, 38, 159-174. [CrossRef]

56. Podsakoff, P.M.; MacKenzie, S.B.; Lee, J.-Y.; Podsakoff, N.P. Common method biases in behavioral research: A critical review of the literature and recommended remedies. J. Appl. Psychol. 2003, 88, 879. [CrossRef]

57. Grimm, P. Wiley International Encyclopedia of Marketing; John Wiley \& Sons, Ltd.: Hoboken, NJ, USA, 2010.

58. Kock, N. Common method bias in PLS-SEM: A full collinearity assessment approach. Int. J. E Collab. 2015, 11, 1-10. [CrossRef]

59. Pérez, A.; Martínez, P.; Del Bosque, I.R. The development of a stakeholder-based scale for measuring corporate social responsibility in the banking industry. Serv. Bus. 2013, 7, 459-481. [CrossRef]

60. Mael, F.; Ashforth, B.E. Alumni and their alma mater: A partial test of the reformulated model of organizational identification. J. Organ. Behav. 1992, 13, 103-123. [CrossRef]

61. Dagger, T.S.; David, M.E.; $\mathrm{Ng}$, S. Do relationship benefits and maintenance drive commitment and loyalty? J. Serv. Mark. 2011, 25, 273-281. [CrossRef]

62. Ho, H.; Ganesan, S. Does knowledge base compatibility help or hurt knowledge sharing between suppliers in coopetition? The role of customer participation. J. Mark. 2013, 77, 91-107. [CrossRef]

63. Dong, B.; Evans, K.R.; Zou, S. The effects of customer participation in co-created service recovery. J. Acad. Mark. Sci. 2008, 36, 123-137. [CrossRef]

64. Kock, N. WarpPLS 6.0, 6; ScriptWarp Systems: Laredo, TX, USA, 2017.

65. Hair, J.F.; Risher, J.J.; Sarstedt, M.; Ringle, C.M. When to use and how to report the results of PLS-SEM. Eur. Bus. Rev. 2018. [CrossRef]

66. Farrukh, M.; Sajid, M.; Lee, J.W.C.; Shahzad, I.A. The perception of corporate social responsibility and employee engagement: Examining the underlying mechanism. Corp. Soc. Resp. Environ. Manag. 2020, 27, 760-768. [CrossRef]

67. Saeed, A.; Jun, Y.; Nubuor, S.A.; Priyankara, H.P.R.; Jayasuriya, M.P.F. Institutional pressures, green supply chain management practices on environmental and economic performance: A two theory view. Sustainability 2018, 10, 1517. [CrossRef]

68. Hair, J.F.; Sarstedt, M.; Ringle, C.M. Rethinking some of the rethinking of partial least squares. Eur. J. Mark. 2019, 53, 566-584. [CrossRef]

69. Fornell, C.; Larcker, D.F. Evaluating structural equation models with unobservable variables and measurement error. J. Mark. Res. 1981, 18, 39-50. [CrossRef]

70. Hair, J.F., Jr.; Sarstedt, M.; Hopkins, L.; Kuppelwieser, V.G. Partial least squares structural equation modeling (PLS-SEM) An emerging tool in business research. Eur. Bus. Rev. 2014, 26, 106-121. [CrossRef]

71. Kock, N.; Lynn, G. Lateral collinearity and misleading results in variance-based SEM: An illustration and recommendations. J. Assoc. Inf. Syst. 2012, 13, 546. [CrossRef]

72. Nitzl, C.; Roldan, J.L.; Cepeda, G. Mediation analysis in partial least squares path modeling: Helping researchers discuss more sophisticated models. Ind. Manag. Data Syst. 2016, 116, 1849-1864. [CrossRef] 
73. Preacher, K.J.; Hayes, A.F. Asymptotic and resampling strategies for assessing and comparing indirect effects in multiple mediator models. Behav. Res. Methods 2008, 40, 879-891. [CrossRef]

74. Martínez, P.; Pérez, A.; del Bosque, I.R. CSR influence on hotel brand image and loyalty. Academia Revista Latinoamericana De Administración 2014, 27, 267-283. [CrossRef]

75. Pérez, A.; del Mar García de los Salmones, M.; Rodríguez del Bosque, I. The effect of corporate associations on consumer behaviour. Eur. J. Mark. 2013, 47, 218-238. [CrossRef]

76. Su, L.; Huang, S.; van der Veen, R.; Chen, X. Corporate social responsibility, corporate reputation, customer emotions and behavioral intentions: A structural equation modeling analysis. J. China Tour. Res. 2014, 10, 511-529. [CrossRef]

77. Arnould, E.J.; Thompson, C.J. Consumer culture theory (CCT): Twenty years of research. J. Consum. Res. 2005, 31, 868-882. [CrossRef]

78. Lichtenstein, D.R.; Drumwright, M.E.; Braig, B.M. The effect of corporate social responsibility on customer donations to corporate-supported nonprofits. J. Mark. 2004, 68, 16-32. [CrossRef]

79. Sen, S.; Bhattacharya, C.B.; Korschun, D. The role of corporate social responsibility in strengthening multiple stakeholder relationships: A field experiment. J. Acad. Mark. Sci. 2006, 34, 158-166. [CrossRef]

(C) 2020 by the authors. Licensee MDPI, Basel, Switzerland. This article is an open access article distributed under the terms and conditions of the Creative Commons Attribution (CC BY) license (http://creativecommons.org/licenses/by/4.0/). 